\title{
Deteriorating Employment and Marriage Decline in Japan
}

\author{
Shigeki Matsuda, Takayuki Sasaki
}

\begin{abstract}
As is the case in Western countries, more Japanese are marrying later or remaining unmarried and are postponing childbearing or staying childless. Previous studies revealed that those individuals who were unable to secure regular employment due to the serious recession between the mid-1990s and mid-2000s, labelled a "lost generation," had a very low marriage rate. But what about subsequent cohorts? Using a discrete-time logit model to analyse Japanese Life Course Panel Survey data, this study investigates the effects of employment on first marriages between 2007 and 2015, including cohorts after the lost generation. The results indicate that: (a) among men who are classed as non-regular employees, unemployed, or low-income regular employees, the likelihood of first marriage is low due to their weak economic position; and (b) women have a low likelihood of first marriage if they are non-regular employees or unemployed, not because of their employment status but because they have less chance of meeting a romantic partner and also because of their values regarding work and marriage. These explicit gender differences in the findings contradict observations made in contemporary Europe and North America, where a trend towards gender convergence in the effects of employment and earnings on marriage has been identified. The ambivalence towards gender equality in family and the workplace will be discussed to understand why many young Japanese remain single.
\end{abstract}

Keywords: Marriage $\cdot$ Low fertility $\cdot$ Employment $\cdot$ Romantic partner $\cdot$ Values

\section{Introduction}

During the last half century, there have been dramatic changes in family formation behaviour in most developed countries. As is the case in Western countries, more Japanese are marrying later or remaining unmarried and are postponing childbearing or staying childless. According to census data, the mean age at first marriage was 26.9 for men and 24.2 for women in 1970, with the figures jumping to 31.1 for men and 29.4 for women in 2015. In 1970, 11.7 percent of men and 7.2 percent of 
women aged 30 to 34 years had never been married. By 2015, those numbers had reached 47.1 percent and 34.6 percent respectively. In the mid-1970s, the Japanese total fertility rate (TFR) sank below replacement level and has remained low ever since. In 2005, this figure reached a record low of 1.26 . It recovered slightly the following year but has now plateaued at 1.36 as of 2019. Unlike Western countries, however, premarital cohabitation and extra-marital childbirths have not become common among Japanese. The percentage of childbirths outside marriage in Japan is only 2 percent, and is significantly lower than the OECD average of 40 percent in 2016 (OECD family database 2018). In Japan, strong social norms link marriage with childbirth (Ochiai 2013), and cohabitation or out-of-wedlock births are not accepted as valid alternatives to the institution of marriage, as is the case in Western countries (Raymo et al. 2015). It is therefore important to examine whether factors associated with the retreat from marriage among Japanese are similar/dissimilar to what has been found in other countries. There are multiple factors that determine the timing of marriage. Among them, the individual economic circumstances of young people have been found to be associated with family formation. As the economic power of women rises, however, the opportunity costs of marriage and parenting would increase.

The purpose of the present study is to investigate whether existing theories in the West can apply to Japan, where social and cultural backgrounds are different. The significance of targeting Japan for this research is as follows. First, Japan is undergoing a rapid trend toward late marriage that is linked closely to the circumstance of youth employment. Since the burst of the bubble economy in the 1990s, unique employment practices in Japan have caused employment conditions to deteriorate, especially for young people. In addition, unlike Western countries, the traditional gender role of women in the home (bearing responsibility for housework and childcare) is still emphasised in Japan. We will shed light on the nature of marital process differences by focusing on employment practices and gender equality both in the family and at the workplace. Specifically, we examine how unstable jobs and low economic resources affect marriage timing among Japanese men and women, and discuss why gender differences, if there are any, exist.

\subsection{Theoretical considerations}

In Western countries, economic circumstances have long been identified as an important predictor of family formation (Thornton et al. 2007) as a secure financial foundation is one of the conditions that young people need before starting family formation. When their income level falls due to recession, their marriage timing tends to be delayed (Sobotka et al. 2011). The timing of a couple's marriage is affected in particular by the man's income level. Indeed, a large body of literature has almost universally highlighted that men's economic resources, such as earnings and employment status, are strong predictors of a transition to first marriage in Europe (Blossfeld et al. 2005; Kalmijn 2011), in the United States (Burstein 2007; McClendon et al. 2014), in Israel (Raz-Yurovich 2010) and in Egypt (Salem 2016). In East Asian countries, economic stagnation and growing economic inequality fol- 
lowing the Asian economic crisis in the 2000s was one of the factors that delayed family formation among the younger generation, especially those at the low end of the socioeconomic spectrum (Raymo et al. 2015).

Women's economic circumstances have a much more complex impact on marriage. According to Becker's theoretical model of marriage $(1973,1981)$, individuals are assumed to rationally choose whether or not to marry based on the gain that can be maximised from the decision. Thus, women's economic independence could discourage women from entering into marriage because marriage and parenthood would increase their opportunity costs. Oppenheimer $(1988,1994)$ questioned this economic perspective and found that highly educated women may delay marriage to pursue their own careers but are more likely to find potential partners. In other words, women with economic resources were not expected to forego marriage but postpone it.

Empirical results in Western countries often showed that the link between women's economic resources and marriage had been negative in older cohorts (Burgess et al. 2003), but has become positive for more recent cohorts (Kuo/Raley 2016; Schneider et al. 2019). The magnitude of this association is, however, relatively weak compared with that for men (Burstein 2007; Shafer/James 2013). One explanation for this dramatic turnaround is related closely to a social trajectory towards gender equality. If women were not provided with opportunities equivalent to those of men in education and the labour market, marriage would be less attractive for highly educated women with a promising career. As Inglehart and his colleagues (Inglehart/Baker 2000; Inglehartet al. 2002) and Lesthaeghe (1983) predicted, we have witnessed that beliefs regarding gender roles have become more egalitarian, life course decisions have been subject to individual needs as well as weakening social and institutional constraints, and the division of labour has become less gendered than in the past. In such egalitarian settings, the costs of family formation can be shared between both men and women. Furthermore, those who have stable employment and earnings, regardless of gender, may possess stronger marriageability. This rationale has been supported by cross-national studies (Blossfeld 1995; Ono 2003). In countries with a large gender gap, women's economic resources have been found to decrease the likelihood of marital transition. In contrast, women's economic resources have been found to increase the likelihood of marital transition in countries where gender roles are less rigid. Matsuda (2019) compared the relationship between marital status and employment conditions among men in six countries using cross-sectional data (Japan, Korea, Singapore, UK, France, and Sweden), and found that non-regular employment, low income, and unemployment are associated with being unmarried. The magnitude of the association was much stronger in Asia, especially in Japan, than in Europe. This finding suggests that persistent social norms about male breadwinning roles are deeply instilled among Japanese. Considering that gender disparity in Japan is among the highest in the world (World Economic Forum 2019), the process of transition to marriage is expected to differ depending on gender. 


\subsection{Labour market and marriage in the japanese context}

Traditionally, Japanese companies simultaneously hired new graduates once a year in accordance with a Japanese employment practice that emphasised senioritybased promotion and lifetime employment. Due to the collapse of the bubble economy in the early 1990s, however, Japanese companies were forced to change this practice in order to reduce labour costs. Because the Labour Standards Law restricts employee dismissal for the purpose of reorganisation, many Japanese companies limited the number of young regular employees hired during the recession (Genda 2004). In response to labour market conditions, employment regulations became more flexible, and the number of non-regular employees increased. In 1990, the share of workers aged between 25 and 34 who were non-regular employees stood at just 3.2 percent for men and 28.2 percent for women, before soaring to 16.6 percent for men and 40.9 percent for women in 2015 (Japan Cabinet Office 2019). Non-regular employees receive significantly lower wages than regular employees and have fewer chances of obtaining regular employment status due to the very low level of career mobility in Japan. Japanese companies continued to hire regular employees through the bulk recruitment of new graduates and minimised mid-career recruitment (Kosugi 2010).

Furthermore, regular employees' income has decreased since the 1990s. In 1997, the percentage of regular employees with annual incomes of less than three million yen was 43 percent among workers in their 20 s and 11 percent among those in their $30 \mathrm{~s}$, but these figures had increased to 50 percent and 19 percent respectively a decade later (Matsuda 2013). Brinton (2011) called this change in employment condition "lost in transition" as the increase in non-regular employees and a decline in income made it difficult for Japanese young people to transition to a stable career and marriage. Considering these unique conditions in the Japanese labour market, the present study tests "the employment deterioration hypothesis" (Matsuda 2019, 2020), which posits that deteriorated employment conditions due to globalisation, service industrialisation, and industrial sophistication result in lower marriage rates. It is important to disentangle the impact of income and employment status although both reflect employment deterioration. Earnings emphasise the financial aspects of employment, with a focus on whether individuals are able to fulfil the role of provider. On the other hand, employment status encompasses a vague sense of uncertainty about the future because non-regular employees often lack proper social security protection and conversion to the status of regular employees is rare in Japan.

Raymo et al. (2015) argues that the tension between rapid changes in the socioeconomic spheres and limited changes within the family sphere underlies the hesitation for family formation in East Asia. Japanese women's labour participation rate in 2017 was 67.4 percent, above the OECD average and even higher than that of US and France. However, almost half of first-time mothers who held a job before pregnancy quit their job following the birth of a child while their husbands remained part of the labour force during the transition to parenthood (NIPSSR 2016). Many mothers return to the labour market after several years of parenting but in the form of non-regular employment. While the employment rate of women increased, women 
are also often responsible for the lion's share of housework and childcare. In Japan, where gender roles are highly asymmetric, female hypergamy remains strong because there are social and institutional constraints that limit women's opportunities (Jones et al. 2009; Raymo et al. 2015). When never-married individuals are asked what they look for in marriage partners, a large gender difference emerges in that twice as many women as men consider earnings, occupation, and academic background when selecting a potential partner (NIPSSR 2016).

Several attempts have been made to clarify the temporal context in Japan using longitudinal data. Men's first jobs and women's education have often found to be linked to their first marriage. Sakai and Higuchi (2005) used the retrospective data from the first wave of the Keio Household Panel Survey and showed that both men and women who were unemployed or had a non-regular job one year after completing their education were less likely to get married or more likely to delay their first marriage. This trend was especially true for those who graduated after 1992. Tsuya (2011) studied a sample of individuals born between 1955 and 1986 and found that the likelihood of first marriage was low among men whose first job was non-regular and women whose educational level was high. When looking at a sample born between 1935 and 1954, however, men's employment status was not a predictor of the likelihood of first marriage (Tsuya 2018). This suggests that men's employment status at their first job has a stronger impact on family formation among the younger cohorts.

In addition to the first job, individuals' work history has found to be associated with family formation. Using detailed life history data of a cohort born between 1966 and 1980, Sasaki (2012) investigated how the effects of individuals' employment status on their first marriage changed as they age. The results revealed that men who were unemployed, self-employed, or non-regularly employed in the previous year were far less likely to get married than regularly employed individuals; the gap was especially wide when the men were in their late 20s and early 30 s. Using the same data, Mugiyama (2017) discovered that transition to first marriage occurred less frequently among both men and women when one consistently had a non-regular job in the previous three years. Piotrowski et al. (2015) analysed another set of retrospective life history data of a cohort born between 1970 and 1973 and found that having a non-regular job hampered family formation even after five years, and that the effect for men is much stronger than for women.

Overall, existing studies have provided evidence that the likelihood of first marriage is significantly low if Japanese men have a non-regular job, regardless of when it occurred in his work history. Historically, Japanese women's employment conditions seem to play a less vital role in determining marriage, but studies with more recent cohorts suggest a possible increase in the impact of women's employment on first marriage (Mugiyama 2017; Piotrowski et al. 2015; Sasaki 2012). However, these studies were based on retrospective data; subjective data as well as objective data that are hard to recall were therefore not collected. One exception is a study conducted by Fukuda (2007), who used prospective data with a female sample born between 1960 and 1983. Although he did not include employment status in the model, he found that women whose annual income is around the national average 
are most likely to get married, compared with other women. This study may be indicative of the changing gender roles in Japan, but this is unknown without comparing men and women.

The present study makes a major contribution to the literature by investigating the effects of employment on first marriage in Japan, for both men and women, using prospective longitudinal data collected annually since 2007. Through this data, we can test whether the nature of the relationship between employment and first marriage has remained the same in recent years by considering important predicting factors such as annual income, the presence of a significant other, and values about work and marriage. And more importantly, how social and cultural contexts would affect family formation will be discussed.

\subsection{Research questions}

$R O$ 1: Is the likelihood of first marriage low among men and women who have a regular job if their income is low?

Whereas extensive research has shown robust findings that employment status has a major influence on family formation, it is still unclear whether employment status per se can give rise to a decision to get married, since the nature of employment status is multifaceted. Non-regular employees may feel insecure about their future due to their uncertain career path and low income with few opportunities for pay rises, which may lead them to remaining unmarried. While it is true that the proportion of non-regular employment has increased dramatically in recent decades, and with it the percentage of never-married men and women, this explains only part of the causal relationship. Although the proportion of non-regular employees among young men has undoubtedly risen sharply in the last quarter of a century, the figure remains at just 16.6 percent for men in 2015. Given that regular employees' income has fallen in that same period in Japan, regular employees with a low annual income may feel that they are unable to fulfil a providing role even though their job status instils a sense of security thanks to permanent employment contracts and welfare benefits.

The division of labour by gender is often rigid among Japanese married couples, especially after the birth of their first child. Because there is a strong expectation on Japanese men to play the role of breadwinner, those men who lack economic resources are less likely to be chosen as a potential husband. In cross-sectional data, an annual income of three million yen has been found to be a clean-cut threshold as to whether a man will marry (Japan Cabinet Office 2011; Matsuda 2019, 2020), but the effect of income on marriage for women is not well known because many married Japanese women have already withdrawn from the labour market. The prospective nature of the present study allows us to test whether the effects of earning power on first marriage differ by gender even after the effects of employment status are controlled. 
RQ2: Is the likelihood of first marriage low among men and women who have an unstable job because they have less chance of encountering a potential spouse?

Traditionally, Japanese marriages were facilitated by an arrangement of families, kin, or matchmakers rather than by love or mutual attraction. It is only in recent decades that a majority of young men and women have been able to choose their own partner. At the same time, the lack of a suitable partner) has continuously been cited as the primary reason why Japanese young men and women remain unmarried (NIPSSR 2016). Oppenheimer (1988) argues that individuals look for potential spouses until they find one who satisfies the minimum qualifications needed to have an acceptable married life. Using a name generator approach to assess personal networks, Matsuda (2015) found that the proportion of regular employees in a respondent's daily contacts was much smaller if respondents themselves were non-regular employees, and non-regular employees were less likely to have a romantic partner than those individuals who were regularly employed. This suggests that individuals with unstable employment are not only less likely to marry, but also that their chances of meeting a romantic partner are smaller.

A deterioration in the employment situation due to macroeconomic conditions greatly reduces the absolute number of available single men who can afford to fulfil the role of provider. This may have a major impact on women with a precarious job because the chance to meet a potential marital partner with a stable employment status within the range of daily contacts is small (Matsuda 2015). The present study investigates whether the effects of employment status on first marriage would be sustained, even after controlling for the presence of a romantic partner to test if the mate selection process is different for men and women.

RQ3: Do attitudes towards work and/or marriage predict the likelihood of first marriage among men and women?

Attitudes and values are important mechanisms affecting individual life events, including employment, marriage, and childbirth (Easterlin 1980; van de Kaa 1987; Lesthaeghe 2002, 2010). Ajzen and his colleagues (Ajzen 2012; Ajzen/Kobas 2013; Fishbein/Ajzen 1975) built a theoretical framework to delineate how attitudes towards a particular behaviour, along with social pressure, predict intentions and how intentions then predict behaviour. Barber et al. (2002) empirically tested the framework and found that positive attitudes towards marriage and childbearing lead to earlier family formation. They also found that positive attitudes towards educational attainment and career pursuits have a negative impact on family formation because these individuals see a conflict between their career or educational goals on the one hand and the requirements of a family on the other. Although eight waves of a longitudinal study were used for the analysis above, neither the effects of employment status nor income level were included in the model. This study will examine to what extent attitudes regarding work and/or marriage affect the decision to marry, after considering the effects of employment conditions.

The vast majority (around 90 percent) of never-married Japanese men and women have continuously reported that they intended to marry at some point in the future (NIPSSR 2016), but fewer and fewer Japanese are actually able to fulfil this 
wish. This implies that personal as well as contextual obstacles prevent them from enacting their intended goal (i.e. marriage). Given that family obligations and expectations are still strong in Japan, the opportunity cost of marriage is high, especially for economically independent women (Bumpass et al. 2009). Similarly, attitudes towards work and/or marriage may act differently for men and women and the association may differ depending on individuals' employment stability.

\section{RQ4: Have the effects of employment status on first marriage persisted over recent} years?

In addition to individual employment conditions, macro-level economic conditions can exert an influence on family formation (Sobotka et al. 2011). In particular, men and women whose position in the labour market is precarious are likely to forgo or postpone family formation during economic recession (Blossfeld/Mills 2005). In Japan, those who entered the labour market between the mid-1990s, when Japan's bubble economy burst, and the mid-2000s are often labelled as the "lost generation" (Asahi-Shimbun "Lost Generation" Shuzai-han 2007) given the extreme difficulty experienced by these individuals in finding a regular job in the deteriorating labour market. Increasing numbers of young people had to settle for non-regular jobs with low income, leading to their economic dependence on ageing parents as well as to delayed marriages (Brinton 2011). As mentioned above, the existing body of empirical research using Japanese longitudinal data (e.g. Mugiyama 2017; Piotrowski et al. 2015; Sasaki 2012; Tsuya 2011, 2018) focused on the relationship between employment and marriage in the 1990s and established that non-regular employees were less likely than regular employees to marry, particularly in the case of men. However, whether such findings continued to remain valid through the 2010s requires further investigation. After the financial crisis in 2008, the Japanese economy was relatively stable. Thus, the present study aims to examine the effects of young adults' employment conditions on their marriage status in post-economic recession Japan using prospective longitudinal data.

\section{Methods}

\subsection{Data}

The data used for this study are derived from the Japanese Life Course Panel Survey (JLPS) conducted by the Institute of Social Science at the University of Tokyo. A nationally representative sample of men and women aged between 20 and 40 years in 2007 was asked about the timing of their major life events, including education, employment, and family formation, as well as their attitudes and values towards such events. Individuals have since been followed on an annual basis. This study is based on the first nine waves of their ongoing panel study. Men and women aged between 20 and 34 years who were unmarried at wave 1 in 2007 (926 men and 861 women) were the focus of the present study. By examining this sample, we can investigate the mechanisms of family formation in Japan for both men and 
women among more recent cohorts than those used in previous studies. Existing Japanese research examining marital union retrospectively collected the detailed life course trajectories, including academic background and work history; however, it is difficult to assess circumstantiated states, thoughts, and beliefs in the past. Thus, another important strength of this data is that pivotal time-variant predictors, such as annual income and attitudes and values towards marriage and work, can be incorporated into the analysis.

\subsection{Measures}

The dependent variable in the present analysis is a dichotomous indicator equal to 1 if a respondent experienced their first marriage in the survey year, and 0 otherwise. Employment status is our primary independent variable of interest and is categorised into four different employment statuses: regular employment, non-regular employment, self-employed, and not in the labour force. Regular employment is a permanent employee with no fixed term of employment. Typical employment statuses for non-regular employment include part-time workers, contract workers, dispatched workers and temporary workers, and their term of employment is normally fixed. Given that income is decreasing even among those who have a regular job, and those whose annual income is less than three million yen are likely to remain unmarried (Japan Cabinet Office 2011; Matsuda 2019, 2020), it is important to distinguish between regularly employed individuals whose income is high and those whose income is low. We therefore use three million yen as a cut-off point for the following analysis.

Each year, respondents are asked whether they have an ongoing romantic partner, which is used to create a dummy variable representing the presence of a romantic partner. Attitudes towards work and marriage are assessed biannually by asking to what extent "success in work" (= importance of work) and "marrying and living a happy family life" (= importance of married life) are important to respondents on a three-point scale $(1=$ very important, $2=$ a little important, $3=$ not important). The values are reverse-coded so the higher scores represent a higher degree of importance. Data are complemented by entering the same value with one wave ahead. Respondents' age, age-squared (centred by men's and women's age separately) and educational attainment are also included as control variables.

\subsection{Analysis strategy}

Discrete-time event history analysis will be conducted to estimate the conditional probability of marriage occurring, given that it has not yet done so. We set 2007, wave 1 of the survey, as the beginning of the observation and examine how the hazard rate depends on time (survey year) and the explanatory variables. Alternatively, one could set a certain age as a starting point of the risk period. However, the age range of the current sample was 20 to 34 at wave 1 and no information is available before those ages, except several time-invariant variables including last school attended, first job, and childhood conditions and so forth. We give more priority to 
examining the effects of time-variant variables on marriage than to examining the age at which marriage is likely to happen. For the time-varying explanatory variables, a two-year lag will be given. Piotrowski et al. (2015) compared the robustness of different lags from zero to five years using a Japanese sample and found that the two-year lag fit the model well. This is quite reasonable considering the marital situation in Japan, where it often takes more than a year for a marriage to be completed after the decision to marry is made. Some people go through multiple rituals and ceremonies that involve both the husband's and wife's families. Logit function will be used for the parameter estimation. We adjusted their standard errors using a heteroscedastic robust procedure (White 1980).

\section{$3 \quad$ Results}

Descriptive statistics for variables used separately in the analysis for men and women are shown in Table 1. The event of first marriage occurred for 9 percent of men and 16 percent of women between wave 1 and wave 9 . The mean age at the time of the first marriage was 29.5 for men and 28.3 for women. The breakdown of the most important explanatory variable, namely the employment status for men was as follows: 60 percent were regular employees, 17 percent were non-regular employees, 17 percent were not part of the labour force, and less than one percent were selfemployed. The percentage of male regular employees who earn three million yen or more and those who earn less than three million yen was about the same (29 percent vs 32 percent). On the other hand, the proportion of female regular employees whose annual income is three million yen or more was much smaller than that of men (17 percent) even though there was no salient difference in the percentage of regular employment by gender. The proportion of non-regular employment among women was much higher than that among men (27 percent vs 17 percent), which indicates that men's employment position is more stable than women's. With regard to the presence of a romantic partner, another important independent variable, the proportion was 28 percent for men and 42 percent for women. There was no significant gender difference in mean values as far as the importance of work and married life are concerned.

Table 2 presents the results of the discrete-time event history analysis for men estimating first marriage. Model 1 shows the effect of employment status after controlling for educational attainment. Compared with regular employees (= reference group), the hazard-odds ratio of first marriage for self-employed individuals in any given year was not significantly different, but it was 0.44 times less for non-regular employees and 0.14 times less for those who were not in the labour force. The results of Model 2, which divided regular employees into two groups by annual income, show that regular employees with annual income of less than three million yen had a significantly lower likelihood of first marriage compared with regular employees with annual income of three million yen or above (= reference group); the hazard-odds ratio of the former was about half that of the latter. In addition, compared with the results of Model 1, the hazard-odds ratio of non-regular employees 
Deteriorating Employment and Marriage Decline in Japan

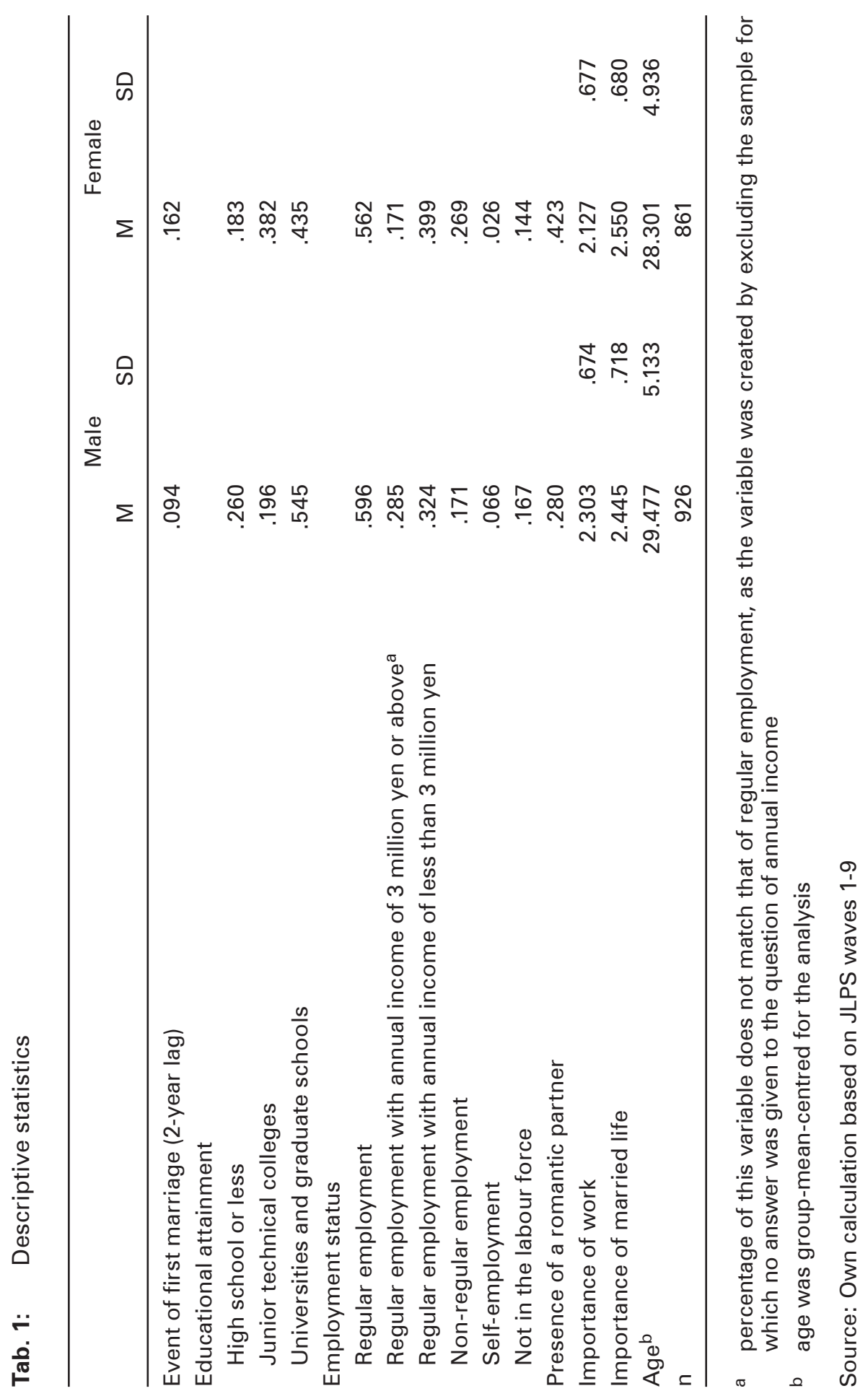




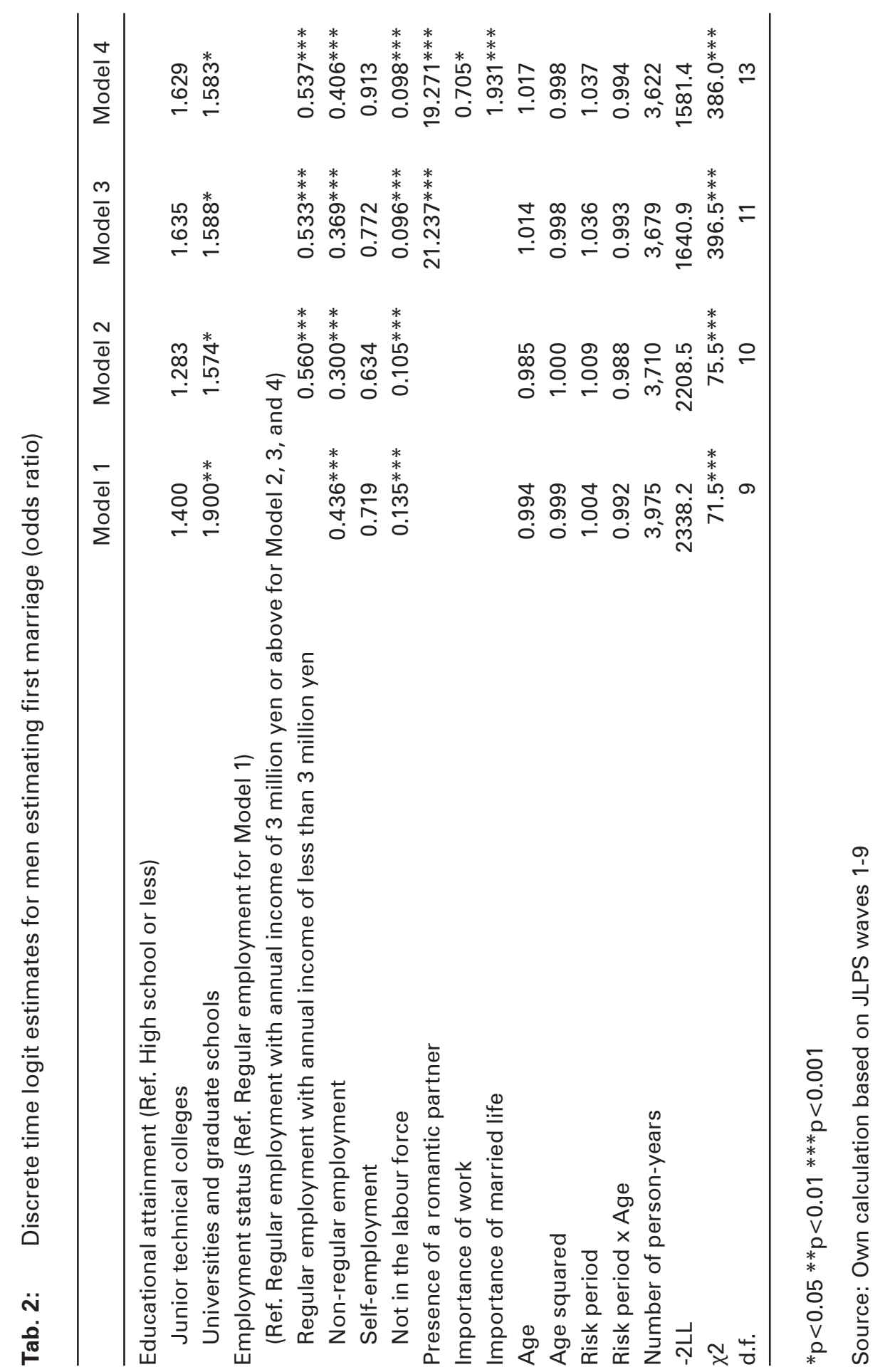


decreased. This indicates that the low likelihood of first marriage of non-regular employees is not only due to their unstable employment situation but also their low income level.

The presence of a romantic partner was added in Model 3, and greatly increased the likelihood of first marriage. Of all the independent variables, the presence of a romantic partner had the greatest effect on whether marriage actually occurred. What should be noted in this model was that factors such as individuals who are regular employees with annual income of less than three million yen, non-regular employees and those not in the labour force continued to have significant effects on marriage rates even after controlling for the presence of a romantic partner.

Individual attitudes towards work and marriage were added in Model 4. While attitudes that emphasise career goals significantly reduced the likelihood of marriage, the attitudes emphasising married life led to a distinct increase in the chances of getting married. Placing importance on marital life had a stronger effect on the first marriage than placing importance on career goals. The effects of employment status remained significant and the coefficients did not change much after controlling for the presence of a romantic partner and attitudes towards occupational life and married life.

Table 3 shows the results for women. Although the magnitude of the effects was relatively small compared with the results for men, the hazard-odds ratio of first marriage for non-regular employees and those not in the labour force was significantly lower than that of regular employees. This is consistent with findings in the West (e.g. Burstein 2007; Shafer/James 2013) and in line with Oppenheimer's argument $(1988,1994)$ that women's economic resources should increase marriage probability. Unlike men, however, the difference between regular employment with annual income at or over three million yen versus income that is less caused no significant difference in the probability of first marriage for women (Model 2). That is, there is no significant difference in the probability based on the level of income among regular employees. The hazard-odds ratio for non-regular employees and those not in the labour force in Model 2 are almost the same as those in Model 1, suggesting that income level has little impact on marriage for women. In addition, women's educational level was not significant (albeit junior technical college graduates were less likely than high school graduates to marry in Model 2). Taken together, women's educational attainment and economic power were not linked to marriage in Japan, which contradicts contemporary findings in the West.

Similar to men's results, the presence of a romantic partner significantly increased the occurrence of first marriage, and its effect was the most significant variable for women as well (Model 3). However, a gender difference did emerge in the results of employment status. For women, the significant difference between regular employees with a high level of income and non-regular employees in terms of the likelihood of marriage disappeared after controlling for the presence of a romantic partner. The effect of attitudes on the likelihood of first marriage among women was similar to the results obtained for men in Model 4. Again, there was a significant gender difference. The effects of employment status remained significant for men whereas none of the different types of employment status was signifi- 


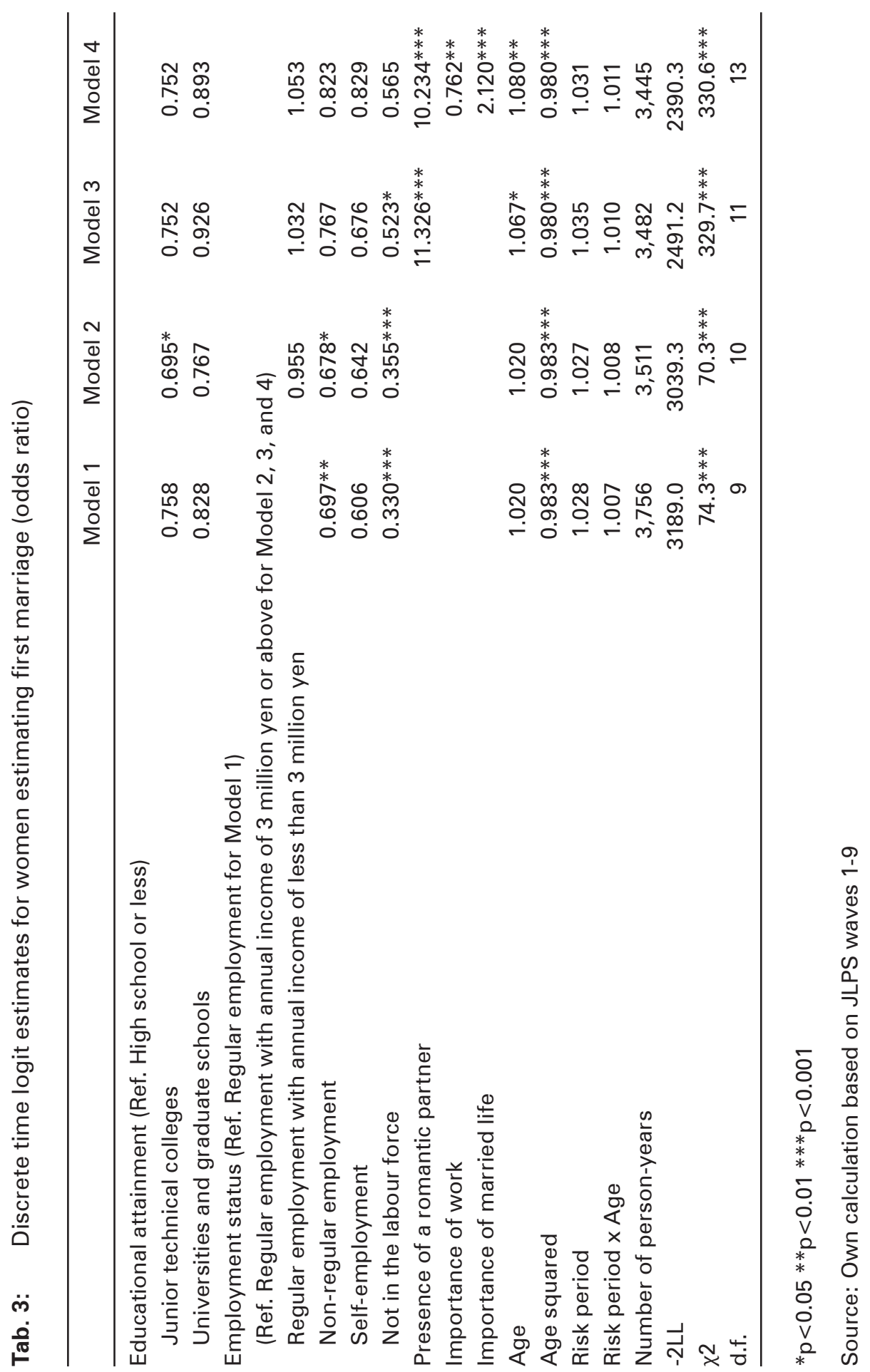


cant after controlling for the presence of a romantic partner and attitudes toward work life and married life among women. Additionally, age was the decisive factor in first marriage likelihood for women, but not for men.

To test these gender differences, samples were pooled and interactions between each variable and gender were estimated (table not shown). For men, employment status and income were significantly linked to marriage, but this was not the case for women. While the presence of a romantic partner had a significant effect on marriage for both men and women, the magnitude was significantly stronger among men. The effects of attitudes towards work and marital life were not statistically different by gender. Neither did the effects of attitudes vary by employment status. We also tested if there is a period effect by entering interaction terms between each variable and risk period (i.e. survey year), but none of them was significant.

\section{Discussion and conclusions}

The present study investigates the effects of employment for both men and women on the likelihood of their first marriage in Japan using prospective longitudinal data. The answers to the four research questions are as follows. First, the likelihood of first marriage is low if men's income is less than three million yen, even when they are regularly employed (RQ1). This finding is not observed among women. This study confirms that men's earning power, even after controlling for employment status, is an important determinant for marriage in Japan where there is a rigid division of gender roles. For Japanese men, having a stable job is not enough to get married but being able to fulfil the role of the breadwinner is critical.

With respect to $\mathrm{RQ2}$, there is a significant gender difference. For men, economic difficulties are the reason why a deterioration in employment will affect whether or not they marry. Regardless of the presence of a romantic partner, the likelihood of marriage among men without a stable job and higher income is remarkably low. For women, in contrast, no matter how much they earn and irrespective of whether their employment status is regular or non-regular, there is no statistically significant difference in the likelihood of marriage after controlling for the presence of a romantic partner. This suggests that opportunities to meet potential partners with a regular employment status and a high level of income are limited if women have an unstable job. Because individuals in non-regular employment have a smaller share of regular employees in their daily contacts (Matsuda 2015), it is more difficult for women than for men to meet their potential marital partners who satisfy marriage conditions (i.e. higher income and stable employment).

The third research question sought to examine the effects of attitudes on marriage. Similar to the findings of Barber et al. (2002), this study reveals that individual work-oriented attitudes reduce the likelihood of first marriage, while married lifeoriented attitudes increase the likelihood of first marriage. Given that both effects are very strong for men and women, it seems that an individual can achieve a life course that suits their values to some extent. However, the results give a distinctive insight for each gender. Whereas men's employment conditions remain a strong 
determinant of marriage, women's employment conditions are no longer significant after the presence of a romantic partner and their attitudes are considered. For women, willingness to give up career success and willingness to form a warm family environment (mainly by providing a caring role) are more important than financial contribution to the family for marital union. This matches earlier observations that there is less of an emphasis on the financial contribution to a household among women than there is among men.

The answer to RQ4 is apparent among men. In line with previous studies, the negative impact on family formation of having an unstable job has persisted in young adults from those who married in the 1990s up until the 2010s. Data from several sources have indicated that macro-level economic conditions can exert an influence on family formation, especially for those who have an unstable job (Blossfeld) Mills 2005; Sobotka et al. 2011). It is quite possible that marriage-inhibiting effects of precarious jobs could have weakened given that the Japanese economy was relatively stable in the 2010s. Because current data only cover marriages that took place between 2007 and 2015, we are not able to test directly whether the effects of employment status changed when compared with the 1990s. However, the likelihood among non-regular employees and those not in the labour force compared with regular employees in this study (the magnitude of the coefficient) was almost the same as the result of previous studies focusing mainly on marriage in the 1990s and 2000s using different samples (Sasaki 2012). In terms of its extent, therefore, the low likelihood of men in non-regular employment and those not in the labour force actually transitioning to marriage did not change very much until the mid-2010s.

At the same time, however, whether the effects of women's employment on marriage have changed over time is unclear. Previous Japanese studies often found that the likelihood of marriage among women who have university degrees or a higher qualification is small (Mugiyama 2017; Sasaki 2012; Tsuya 2018), but the results linking women's employment status and marriage have been mixed. Some (Fukuda 2007; Sasaki 2012) argue that the stability of women's employment may have been more important for marital union than in the past because women have increasingly been expected to contribute to family finances in response to the deterioration in the labour market. Indeed, in 1992, 30.4 percent of unmarried men wanted their potential partner to be a housewife but this figure had dropped to 10.1 percent by 2015. Similarly, while 10.8 percent of unmarried men wanted their potential partner to continue to work during the transition to parenthood in 1992, the figure had jumped to 33.9 percent by 2015 (NIPSSR 2016). In contrast, the findings from the present study suggest that neither women's income nor stable employment necessarily increase marriageability, even among those who married in more recent years compared with samples in past studies.

These explicit gender differences in the findings contradict what has been observed in contemporary Europe and North America, where a trend towards gender convergence in the effects of employment and earnings on marriage has been identified (Burstein 2007; Kuo/Raley 2016; Schneider et al. 2019; Shafer/James 2013). This discrepancy could be attributed to the ambivalence towards gender equality in Japanese society. As is the case in Western countries, the last 50 years have seen 
gender ideology become more egalitarian, with more and more Japanese believing that men and women should be treated equally. Even so, beliefs about the importance of women's employment outside of the home was an exception, possibly because of the symbolic value of the housewife role as well as social and institutional constraints on married women's full participation in the labour market (Lee et al. 2010). Changes in the roles of men and women in the home are much slower than socio-economic development in Japan (Raymo et al. 2015). According to the International Social Survey Programme (2012), a majority of Japanese men and women agree that being a housewife is as fulfilling as working for pay whereas the opposite is true for most European countries. Lee et al. (2010) mentions that the role of the housewife in Japan may not be viewed as oppressive and may have a different significance than in many Western countries. Firm norms of intensive maternal investment in the family persist, together with traditions of intergenerational exchange of support, sometimes by living together with own parents or in-laws. Such strong expectations and obligations for mothers are likely to be seen as unattractive to Japanese women who have more life options outside of the family (Bumpass et al. 2009).

Social and economic sanctions against married women's full-time employment also encouraged the gendered division of labour, while the basic principle of ensuring gender equality has been advocated. By limiting a wife's annual income, she will be exempt from having to pay resident tax and income tax, pension premiums and health insurance premiums, and her husband can receive a stepwise tax deduction in stages if his wife is a dependent. Consequently, many women often give up their regular job once they give birth to their first child because difficulties they face in reconciling work and family life become more of a burden rather than a form of liberation. Considering the low career mobility in employment, it is extremely difficult for women to pursue a career with promotion opportunities. All of the above make Japan a country with one of the largest wage gaps by gender as well as the smallest share of female managerial positions in developed countries (OECD 2017).

Although more Japanese men and women believe that women should continue to work during the transition to parenthood in order to share the role of provider (NIPSSR 2016), social and institutional barriers prevent such lifestyles. In that context, women, regardless of their economic resources, are likely to seek a husband who has a stable job with a high level of income because Japanese women can clearly see the glass ceiling. Thus, the findings from the present study suggest that gender gaps in the family and the workplace have a strong impact on mate selection in Japan.

\subsection{Limitations and challenges to the future}

This paper has clarified that non-regular employment and low income in recent years have reduced the likelihood of first marriage for young people. However, the unmarried rate and fertility rate in Japan vary widely from region to region. For example, although income levels are highest in Tokyo and lowest in Okinawa, these two prefectures have among the highest lifetime unmarried rates in Japan. Therefore, the effects of employment conditions on marriage may vary from region to re- 
gion. Data limitations prevented us from exploring regional difference in this study, but future studies should consider how regional factors influence the way in which employment affects marriage.

Further study is required in order to clarify whether the employment deterioration hypothesis applies to other countries. Matsuda (2019) analysed the relationship between employment status and marriage using cross-sectional data from Japan, South Korea, Singapore, and three European countries. Although the causal relationship between variables is ambiguous due to restrictions on the data used, marriage probability is affected by employment status and income level in South Korea and Singapore, as it is in Japan. Further work is required to establish the validity of the employment deterioration hypothesis by using longitudinal data with more detailed working conditions, such as working schedules, fringe benefits, and various welfare benefits for employees. Moreover, the effects of macro-level composition in employment status should be compared cross-nationally. If differences in the effects of working conditions on marriage becomes clear, it will be possible to provide policy suggestions for governments in other countries so they can take effective measures against their low fertility.

Finally, the effects of precarious employment and low incomes not only reduce the likelihood of young adults' marrying but might also reduce the number of children they have. In future, we will study the impact of early employment on the overall declining unmarried and birth rates.

\section{Acknowledgements}

This study was supported by the Japan Society for the Promotion of Science, KAKENHI Grant Numbers $18 \mathrm{H} 00936$ and 18K02054. The data for this secondary analysis, Japanese Life Course Panel Survey conducted by the Institute of Social Science, The University of Tokyo, were provided by the Social Science Japan Data Archive, Center for Social Research and Data Archives, Institute of Social Science, The University of Tokyo.

\section{References}

Ajzen, Icek 2012: The theory of planned behavior. In: Lange, Paul A.M.; Kruglanski, Arie W.; Higgins, E. Tory (Eds.): Handbook of theories of social psychology (Vol. 1). London: Sage: 438-459. http://dx.doi.org/10.4135/9781446249215.n22

Ajzen, Icek; Klobas, Jane 2013, Fertility intentions: An approach based on the theory of planned behavior. In Demographic Research 29,8: 203-232. https://doi.org/10.4054/DemRes.2013.29.8

Asahi-Shimbun "Lost Generation" Shuzai han 2007: Lost Generation: Samayou 2000 man nin [Lost Generation: 20 Million People Wandering]. Tokyo: Asahi-Shimbun-sha.

Barber, Jennifer S.; Axinn, William G.; Thornton, Arland 2002: The Influence on Attitudes on Family Formation Process. In: Lesthaeghe, Ron J. (Ed.): Meaning and Choice: Value Orientations and Life Course Decisions. The Hague: NIDI: 45-95. 
Becker, Gary S. 1973: A theory of marriage: Part I. In: Journal of Political economy 81,4: 813-846.

Becker, Gary S. 1981: A treatise on the family. Cambridge: Harvard University Press. https://doi.org/10.1086/260084

Blossfeld, Hans-Peter 1995: Changes in the process of family formation and women's growing economic independence: A comparison of nine countries. In: Blossfeld, Hans-Peter: The new role of women: Family formation in modern societies. Boulder/ San Francisco/Oxford: Westview Press: 3-32.

Blossfeld, Hans-Peter; Mills, Melinda 2005: Globalization, uncertainty and the early life course: A theoretical framework. In: Blossfeld, Hans-Peter et al. (Eds.): Globalization, uncertainty and youth in society. London/New York: Routledge Advances in Sociology Series: 1-24.

Blossfeld, Hans-Peter et al. 2005: Globalization, uncertainty and youth in society: The losers in a globalizing world. London: Routledge.

Brewster, Karin L.; Rindfuss, Ronald R. 2000: Fertility and women's employment in industrialized nations. In: Annual Review of Sociology 26: 271-296. https://doi.org/10.1146/annurev.soc.26.1.271

Brinton, Mary C. 2011: Lost in Transition: Youth, Work, and Instability in Postindustrial Japan. New York: Cambridge University Press.

Bumpass Larry L. et al. 2009: The institutional context of low fertility: the case of Japan. In: Asian Population Studies 5: 215-235. https://doi.org/10.1080/17441730903351479

Burgess, Simon; Propper, Carol; Aassve, Arnstein 2003: The role of income in marriage and divorce transitions among young Americans. In: Journal of Population Economics 16,3: 455-475. https://doi.org/10.1007/s00148-003-0124-7

Burstein, Nancy R. 2007: Economic influences on marriage and divorce. In: Journal of Policy Analysis and Management 26,2: 387-429. https://doi.org/10.1002/pam.20257

Easterlin, Richard 1980: Birth and Fortune: The Impact of Number on Personal Welfare. New York: Basic Book.

Fishbein, Martin; Ajzen, Icek 1975: Belief, Attitude, Intention and Behavior: An Introduction to Theory and Research. Reading, MA: Addison-Wesley.

Fukuda, Setsuya 2007: Gender system to josei no kekkon sentaku (2): Nihon ni okeru joseino keizaiteki jiritsu kasetu no kenshou [Gender System and Choice of Marriage (2): A Test of the Economic Independence Hypothesis among Women in Japan]. In: Japanese Journal of Research on Household Economics 76: 54-62.

Genda, Yuji 2004: Job Creation. Tokyo: Nihon Keizai Shimbun-sha.

Inglehart, Ronald; Baker, Wayne E. 2000: Modernization, cultural change, and the persistence of traditional values. In: American Sociological Review 65,1: 19-51. https://doi.org/10.2307/2657288

Inglehart, Ronald; Norris, Pippa; Welzel, Christian 2002: Gender equality and democracy. In: Comparative Sociology 1,3-4: 235-264.

Iwasawa, Miho 2015: Shoshika wo motarashita mikonka oyobi fuuhu no henka [Decline of Marriage Rates and Changes of Couples' Behavior Causing Low Fertility]. In: Takahashi, Shigesato; Ohbuchi, Hiroshi (Eds.): Jinkou gensho to shoshika taisaku [Depopulation and Countermeasures against Low Fertility]. Tokyo: Hara Shobo: 49-72.

Japan Cabinet Office 2011: Heisei 22 nendo Kekkon Kazoku Keisei ni kansuru Tyousa Houkokusho [A 2011 Survey Report on Marriage and Family Formation]. Tokyo. 
Japan Cabinet Office 2019: Reiwa gan nendo Danjo kyodo-sankaku Hakusho [A 2019 Gender equality White Paper]. Tokyo.

Jones, Gavin W.; Straughan, Paulin Tay; Chan, Angelique 2009: Ultra-Low Fertility in Pacific Asia: Trends, Causes and Policy Issues. Abingdon: Routledge.

Kalmijn, Matthijs 2011: The influence of men's income and employment on marriage and cohabitation: Testing Oppenheimer's theory in Europe. In: European Journal of Population/Revue européenne de Démographie 27,3: 269-293. https://doi.org/10.1007/s10680-011-9238-x

Kosugi, Reiko 2010: Wakamono to Shoki Carrer [Youth and Early Carrer]. Tokyo: Keisoshobo.

Kuo, Janet Chen-Lan; Raley, Kelly R. 2016: Is it all about money? Work characteristics and women's and men's marriage formation in early adulthood. In: Journal of Family Issues 37,8: 1046-1073. https://doi.org/10.1177/0192513X14530973

Lee, Kristen Schultz; Tufiş, Paula A.; Alwin, Duane F. 2010: Separate spheres or increasing equality? Changing gender beliefs in postwar Japan. In: Journal of Marriage and Family 72,1: 184-201. https://doi.org/10.1111/j.1741-3737.2009.00691.x

Lesthaeghe, Ron J. 1983: A century of demographic and cultural change in Western Europe: An exploration of underlying dimensions. In: Population and development Review 9,3: 411-435. https://doi.org/10.2307/1973316

Lesthaeghe, Ron J. 2002: Meaning and Choice: Value Orientations and Life Course Decisions. NIDI-CBGS monograph. The Hague: NIDI.

Lesthaeghe, Ron J. 2010: The Unfolding Story of the Second Demographic Transition. In: Population and Development Review 36,2: 211-251. https://doi.org/10.1111/j.1728-4457.2010.00328.x

McClendon, David; Kuo, Janet Chen-Lan; Raley, Kelly R. 2014: Opportunities to meet: Occupational education and marriage formation in young adulthood. In: Demography 51,4: 1319-1344. https://doi.org/10.1007/s13524-014-0313-x

Matsuda, Shigeki 2013: Shoshika ron: Naze mada kekkon shussan shiyasui kunini naranainoka [The Theory of the Declining Birth Rate: Why Isn't Japan a Society in Which It Is Easy to Marry and Give Birth?]. Bunkyo-ku: Keiso shobo.

Matsuda, Shigeki et al. 2015: Shokuba ni okeru Deai to Kekkon lyoku no Kankei, Naikakufu Keizai Shakai Sougou Kenkyusho. ESRI Discussion Paper Series No. 323, Shoushika to Mikonjosei no Seikatsu kankyo ni Kansuru Kenkyu [The Relationship between Workplace Encounters and Willingness to Marry, ESRI Discussion Paper Series No. 323. Analysis of the Relation between Low Fertility and Living Conditions among Never-Married Women. Empirical Evidence from Survey Data]. Economic and Social Research Institute: 32-57.

Matsuda, Shigeki 2019: Young Men's Employment and Their Marriage: A Comparison among Japan, South Korea, Singapore, the UK, France, and Sweden. In: Comparative Sociology 18,2: 1-25. https://doi.org/10.1163/15691330-12341491

Matsuda, Shigeki (Ed.) 2020: Low Fertility in Advanced Asian Economies: Focusing on Families, Education, and Labor Markets. Singapore: Springer. https://doi.org/10.1007/978-981-15-0710-6

Mugiyama, Ryota 2017: Employment History and Transition to Marriage: Different Effect of Employment Status, Occupation, Firm Size, and Associated Changes According to Gender. In: Japanese Journal of Family Sociology 29,2: 129-141. https://doi.org/10.4234/jioffamilysociology.29.129 
NIPSSR (National Institute of Population and Social Security Research) 2016: The Fifteenth National Fertility Survey. Tokyo: NIPSSR [in Japanese].

Ochiai, Emiko 2013: Kindai sekai no tenkan to kazoku hendou no ronri: Asia to Europe [The Logic of Global Family Change in Transforming Modernity: Focusing on Asia and Europe]. In: Japanese Sociological Review 64,4: 533-551. https://doi.org/10.4057/jsr.64.533

OECD 2017: The pursuit of gender equality: An uphill battle. https://dx.doi.org/10.1787/9789264281318-en

OECD family database 2018: Share of births outside of marriage [https://www.oecd.org/ els/family/SF_2_4_Share_births_outside_marriage.pdf, 21.07.2020].

Ono, Hiromi 2003: Women's economic standing, marriage timing, and cross-national contexts of gender. In: Journal of Marriage and Family 65,2: 275-286. https://doi.org/10.1111/j.1741-3737.2003.00275.x

Oppenheimer, Valerie Kincade 1988: A Theory of Marriage Timing. In: American Journal of Sociology 94,3: 563-591. https://doi.org/10.1086/229030

Oppenheimer, Valerie Kincade 1994: Women's rising employment and the future of the family in industrial societies. In: Population and development review 20,2: 293-342. https://doi.org/10.2307/2137521

Piotrowski, Martin; Kalleberg, Arne; Rindfuss, Ronald R. 2015: Contingent Work Rising: Implications for the Timing of Marriage in Japan. In: Journal of Marriage and Family 77,5: 1039-1056. https://doi.org/10.1111/jomf.12224

Raymo, James M. et al. 2015: Marriage and family in East Asia: Continuity and change. In: Annual Review of Sociology 41: 471-492.

https://doi.org/10.1146/annurev-soc-073014-112428

Raz-Yurovich, Liat 2010: Men's and women's economic activity and first marriage: Jews in Israel, 1987-1995. In: Demographic Research 22, 933-964. https://doi.org/10.4054/DemRes.2010.22.29

Sakai, Tadashi; Higuchi, Yoshio 2005: Freeter no sonogo: Shuugyo, shotoku, kekkonn, shussan [Lives after Being a Freeter: Employment, Income, Marriage, and Childbirth]. In: Japanese Journal of Labour Studies 47,1: 29-41.

Salem, Rania 2016: The gendered effects of labour market experiences on marriage timing in Egypt. In: Demographic Research 35: 283-314. https://doi.org/10.4054/DemRes.2016.35.11

Sasaki, Takayuki 2012: Marriage at a Time of Uncertainty: Effects of Earning Potential Using JGSS Life Course Study Data. In: Japanese Journal of Family Sociology 24,2: 152-164. https://doi.org/10.4234/jjoffamilysociology.24.152

Schneider, Daniel; Reich, Adam 2014: Marrying ain't hard when you got a union card? Labor union membership and first marriage. In: Social Problems 61,4: 625-643. https://doi.org/10.1525/sp.2014.12316

Schneider, Daniel; Harknett, Kristen; Stimpson, Matthew 2019: Job quality and the educational gradient in entry into marriage and cohabitation. In: Demography 56,2: 451 476. https://doi.org/10.1007/s13524-018-0749-5

Shafer, Kevin; James, Spencer L. 2013: Gender and socioeconomic status differences in first and second marriage formation. In: Journal of Marriage and Family 75,3: 544-564. https://doi.org/10.1111/jomf.12024

Sobotka, Tomáš; Skirbekk, Vegard; Philipov, Dimiter 2011: Economic recession and fertility in the developed world. In: Population and Development Review 37,2: 267-306. https://doi.org/10.1111/j.1728-4457.2011.00411.x 
Thornton, Arland; Axinn, William G.; Xie, Yu 2007: Marriage and Cohabitation. Chicago: Univ. Chicago Press.

Tsuya, Noriko 2011: Mikonka no genin: Gender kara mita gakureki to koyo [Reason for Marriage Decline: Education and Employment from a Gender Perspective]. In: Atoh, Makoto et al. (Eds.): Shoshika jidai no kazoku henyo: Partnership to shussho koudou [Family Transformation in the Age of Declining Birth-Partnership and Birth Behavior]. Tokyo: Tokyo University Press: 19-42.

Tsuya, Noriko 2018: Koyo to partnership: Gender to cohort no shiten kara [Employment and Partnership: From the Perspective of Gender and Cohort]. In: Tsuya, Noriko et al. (Eds.): Shosi koureika jidai no josei to kazoku: Panel data kara wakaru nihon no gender to oyako kankei no henyo [Women and Families in the Age of Low Fertility and Aging: Transforming Japanese Gender and Parent-Child Relationships from Panel Data]. Tokyo: Keio University Press: 59-69.

van de Kaa, Dirk J. 1987: Europe's Second Demographic Transition. In: Population Bulletin 42,1: 3-55.

White, Halbert 1980: A Heteroskedasticity-Consistent Covariance Matrix Estimator and a Direct Test for Heteroskedasticity. In: Econometrica 48,4: 817-838. https://doi.org/10.2307/1912934

World Economic Forum 2019: Global Gender Gap Report 2020 [http://www3.weforum. org/docs/WEF_GGGR_2020.pdf, 21.07.2020].

Prof. Shigeki Matsuda ( $₫)$. Chukyo University, School of Contemporary Sociology. Toyota, Japan. E-mail: matsuda_z113@yahoo.co.jp URL: https://www.researchgate.net/profile/Shigeki_Matsuda

Takayuki Sasaki. Associate Professor. Osaka University of Commerce, Faculty of Public Affairs. Higashi Osaka, Japan. E-mail: tsasaki@daishodai.ac.jp URL: https://ouc.daishodai.ac.jp/profile/educational_research/teacher/public_affairs/ teacher242.html 


\section{Comparative Population Studies}

WWW.comparativepopulationstudies.de

ISSN: 1869-8980 (Print) - 1869-8999 (Internet)

\section{Published by}

Prof. Dr. Norbert F. Schneider

Federal Institute for Population Research D-65180 Wiesbaden / Germany

\section{(cc) BY-SA}

2020

\section{Managing Editor}

Prof. Dr. Johannes Huinink

Dr. Katrin Schiefer

\section{Editorial Assistant}

Beatriz Feiler-Fuchs

Wiebke Hamann

\section{Layout}

Beatriz Feiler-Fuchs

E-mail:cpos@bib.bund.de

\section{Scientific Advisory Board}

Karsten Hank (Cologne)

Michaela Kreyenfeld (Berlin)

Marc Luy (Vienna)

Natalie Nitsche (Rostock)

Zsolt Spéder (Budapest)

Rainer Wehrhahn (Kiel)

\section{Board of Reviewers}

Bruno Arpino (Barcelona)

Kieron Barclay (Rostock)

Laura Bernardi (Lausanne)

Gabriele Doblhammer (Rostock)

Anette Eva Fasang (Berlin)

Michael Feldhaus (Oldenburg)

Tomas Frejka (Sanibel)

Alexia Fürnkranz-Prskawetz (Vienna)

Birgit Glorius (Chemnitz)

Fanny Janssen (Groningen)

Frank Kalter (Mannheim)

Stefanie Kley (Hamburg)

Bernhard Köppen (Koblenz)

Anne-Kristin Kuhnt (Duisburg)

Hill Kulu (St Andrews)

Nadja Milewski (Rostock)

Roland Rau (Rostock)

Thorsten Schneider (Leipzig)

Tomas Sobotka (Vienna)

Jeroen J. A. Spijker (Barcelona)

Heike Trappe (Rostock)

Helga de Valk (The Hague)

Sergi Vidal (Barcelona)

Michael Wagner (Cologne) 